\title{
Anita ADAMCZYK
}

Poznań

\section{Romni wśród Romów. Kobieta w kulturze romskiej}

Domowie w Polsce należą do mniejszości etnicznych. Nie jest to grupa zbyt liczna. Wh oficjalnych danych pochodzących ze Spisu Powszechnego z 2002 roku, tworzyło ją 12855 osób (z czego 99\% posiadała polskie obywatelstwo) ${ }^{1}$. Cechami wyróżniającymi tę populację spośród innych przedstawicieli mniejszości narodowych i etnicznych była młodość. Osoby w wieku od 0 do 17 lat stanowiły 36,3\%, a w wieku poprodukcyjnym jedynie $4,5 \%$. Nie była to grupa sfeminizowana, ponieważ mężczyźni liczyli $50,26 \%$ ogółu społeczności romskiej.

Mimo niewielkiej reprezentacji jest to społeczność wyalienowana. Poddawana marginalizacji i dyskryminacji na terenie Polski ${ }^{2}$. Postawy te wynikają z braku porozumienia, a to z kolei ma związek z utrzymującymi się negatywnymi stereotypami na temat Romów, nieznajomością w środowisku gadziów (nie Romów) tradycji i kultury romskiej oraz postępującą pauperyzacją (mającą źródła w niedostatecznym wykształceniu, braku pracy i trudnych warunkach mieszkaniowych).

Ograniczone kontakty między przedstawicielami grup romskich a osobami nieposiadającymi ich korzeni sprawiają, iż wiedza gadziów o życiu romskim jest niewielka. Opiera się ona najczęściej na obiegowej opinii, a rzadko na publikacjach naukowych poświęconych Romom. Pozycji książkowych o tej mniejszości jest coraz więcej. Należy jednak zaznaczyć, iż wiele z tych, które ukazały się czterdzieści czy pięćdziesiąt lat temu nie oddająjuż stanu faktycznego - rzeczywistej wiedzy o Romach z XXI wieku. Wiele zmieniło się od tamtych czasów. Przekształceniu uległ styl życia, ubioru, choć tradycje i podział ról na to co męskie i kobiece pozostało.

Kobieta romska w świadomości Polaków uchodzi za osobę obdarzoną urodą o charakterystycznym stroju, posiadającą umiejętności taneczne i śpiewu oraz otoczoną gromadką hałaśliwych dzieci. Postrzegana jest także jako wróżka i złodziejka. Spotkanie z nią otoczone jest magią i strachem. Obserwując środowisko romskie można wysnuć również wniosek, iż kobieta pełni rolę drugorzędną lub służebną wobec swego męża ${ }^{3}$. Jest przez niego źle traktowana i zdominowana.

Jaka jest zatem kobieta romska, czyli romni? Odpowiedź na to pytanie jest trudna, ponieważ Romowie w Polsce nie stanowią jednolitej grupy. Dzielą się na: Polska Roma, Bergitka Roma, Kełderasze, Lowarzy, Sinti. Różnią się między sobą przede wszystkich stopniem przestrzegania zasad zawartych w moralno-etycznym kodeksie postępowania (romanipen), który określa reguły ich zachowań. Największą swobodą charakteryzują się kobiety pochodzące

\footnotetext{
${ }^{1}$ Wyniki Narodowego Spisu Powszechnego Ludności i Mieszkań 2002 w zakresie deklarowanej narodowości oraz języka używanego w domu, www.stat.gov.pl/gus/5840_4520_PLK_HTML.htm (5.07.2009).

${ }^{2}$ Więcej na ten temat: A. Adamczyk, Problematyka dyskryminacji $\bar{w}$ Polsce (na przykładzie Romów), ,Sprawy Narodowościowe" 2005, z. 26.

${ }^{3}$ E. A. Jakimiak, K. Parno Gierliński, Kobieta w środowisku romskim, Szczecinek, s. 5.
} 
z Bergitki Roma, a najmniejszą z Kełderaszy i Lowarów. Jednak ich role i pozycje są podobne. Zmianie może ulec jedynie stosunek do nich ze strony męża czy teściów. Przynależność do wyżej wspomnianych grup ma związek z pochodzeniem matki ${ }^{4}$.

W języku romani, który funkcjonuje w Polsce w sześciu dialektach, określeń odnoszących się do kobiet jest wiele. Związane są one $\mathrm{z}$ wiekiem, powinowactwem w rodzinie oraz ich rolami. Wśród nich można wyróżnić:

— ćhaj lub śaj-córka, dziewczyna,

- romni-kobieta, żona,

- romanduni-mężatka,

- daj-matka,

- chułani-gospodyni,

- kirwi-ciocia (kuma),

- mami-babcia,

- phuri daj-starsza kobieta, matrona.

Pozycja i rola kobiet w środowisku romskim uzależniona jest przede wszystkim od wieku. Będąc małą dziewczynką spędza beztroskie dzieciństwo. Ma pełną swobodę. Wychowanie romskie charakteryzuje się bowiem ogromną tolerancją wobec dzieci. Rodzice nie opuszczają ich i zawsze im towarzyszą. Wiek dziecięcy dla dziewczynki kończy się jednak szybko. Od około 10 roku życia zaczyna uczyć się swojej nowej roli. Jej nauczycielką jest mama, wspomagana przez ciocie, starsze siostry i innych członków rodziny. Poznaje swoje obowiązki jako kobiety, czyli przyszłej żony i matki. Zgłębia zasady obowiązujące w swoim środowisku, poznaje maniery, aby w przyszłości swoim zachowaniem czy sposobem ubioru ich nie naruszyć. Proces socjalizacji młodej romni jest odmienny od przygotowań chłopca do wejścia w dorosłość. Matka odgrywa jedną z najistotniejszych ról w wychowaniu córki, ale to jednak do ojca należy podejmowanie znaczących decyzji o jej przyszłości.

Dziewczynka od dzieciństwa buduje swój wizerunek. Powinna charakteryzować się skromnością, troskliwością i wstydliwością. Ponadto ważna jest także jej obowiązkowość oraz szacunek do starszych. Jej czas bycia ćhaj kończy się wraz z osiągnięciem dojrzałości płciowej, czyli z chwilą pierwszej menstruacji. Od tego momentu rodzina dba o to by była patyvali romni. Pod pojęciem tym rozumie się kobietę godną szacunku oraz dziewicę. Taka romni jest dumą rodziny. Urażenie jej czci może skończyć się skalaniem.

Dojrzała dziewczyna nie może przebywać sama poza domem. Muszą towarzyszyć jej członkowie rodziny, aby nie została posądzona o niewłaściwe zachowanie. Jej postępowanie nie może kojarzyć się z seksualnością. Nie może chodzić na basen czy plażę. Obecność w tych miejscach wymaga odkrycia wielu części ciała, co jest naruszeniem podstawowych zasad romskich. Nie może także nosić okularów (przez całe życie), bo to rzuca cień na jej rodzinę.

Najczęściej w tym okresie kończy się jej edukacja. Ryzyko uprowadzenia młodej dziewczyny przez Roma (mężczyznę) jest bardzo duże. Jest to istotne, ponieważ gdyby do tego doszło, to zgodnie ze zwyczajem po spędzonej wspólnie nocy jest już jego żoną. Gdyby jednak rodzice zgodzili się na kontynuowanie przez nią edukacji, to nie może ona aktywnie uczestniczyć w zajęciach z wychowania fizycznego. Ma to związek z tradycją romską, która nie pozwala kobietom na pokazywanie nóg, które należą do strefy nieczystej.

${ }^{4}$ Ibidem, s. 10.

5 A. Bartosz, Nie bój się Cygana. Na dara Romestar, Sejny 2004, s. 175. 
Niedostateczne wykształcenie Romów jest jedną z największych ich bolączek, które rzutuje na obecne położenie. Dotyczy to zarówno kobiet, jak i mężczyzn. Według danych Spisu Powszechnego z 2002 roku jedynie 0,14\% legitymowała się wyższym wykształceniem ${ }^{6}$. Świadectwo ukończenia szkoły średniej posiadało z kolei 2,62\% Romów. Liczni ukończyli szkołę podstawową - około $40 \%$, a największe grono czyli 51\% skończyło edukację tylko na poziomie trzeciej lub czwartej klasy.

Wykształcona kobieta w środowisku romskim należy do rzadkości. Jej podstawowym obowiązkiem jest bowiem dbanie o rodzinę i męża, a nie zajmowanie się nauką lub karierą zawodową. Istnieje pewna grupa profesji, których wykonywanie jest zabronione. Romni (lub Rom) nie może być na przykład lekarzem, położną, pielęgniarką, policjantką lub pracować w firmie zajmującej się oczyszczaniem miasta. Zawody te zaliczone są do nieczystych.

Romni ma najczęściej jednego męża. Gdyby jednak rozwiodła się to jej matrymonialne zainteresowania mogą dotyczyć tylko wdowców lub rozwodników. Ceremonia ślubna odbywa się zazwyczaj poza kościołem lub urzędem stanu cywilnego. Małżeństwo postrzegane jest jako umowa między rodzinami. Ślubu udziela najczęściej najstarszy z rodu. Żonę można porwać (często za jej zgoda) lub kupić. W tej drugiej formie płaci się za jej dziewictwo. Sprawdzenie jej czystości ma miejsce podczas wesela. W trakcie uroczystości para młoda nie może sobie okazywać uczuć. Kobiety ucztują same podobnie jak mężczyźni. Gdyby mąż po ślubie zostawił swoją wybrankę, a ona była cnotliwa, to musi za to zapłacić. Rozwód zatem jest możliwy i akceptowany we wspólnocie. Tradycyjnie to mąż go proponuje. Rozwód można otrzymać na przykład w przypadku zdrady przez żonę, niedbałości jej o męża czy bezpłodności kobiety. Do rzadkości należą sytuacje, w których to romni zostawia swego mężczyznę.

Kobiety romskie dość szybko wychodzą za mąż. Często są jeszcze dziećmi, które nadal wymagają opieki. Jest to zgodne z prawem romskim, ale narusza normy prawa obowiązujące w państwie polskim. Znane są już przypadki oskarżenia mężczyzn pochodzenia romskiego o obcowanie płciowe z nieletnią. Jednym z nich był osiemnastoletni Rom, który w 2003 roku poślubił piętnastolatkę (a rok później na świat przyszło ich dziecko) ${ }^{7}$. Został on skazany na osiem miesięcy pozbawienia wolności. Sąd jednak karę zawiesił na okres trzech lat i poddał go pod nadzór kuratora. Inny akt oskarżenia o pedofilię w 2006 roku wystosowano wobec dwudziestoczterolatka, który dopuścił się współżycia seksualnego z dwunastoletnią dziewczynką romską. Takich spraw jest jednak niewiele. Społeczność romska żyje we własnym świecie i nie informuje o tym gadziów.

Kobiety wydają na świat kilka dzieci, co wiąże się z romską maksymą im więcej dzieci tym więcej szczęścia. Do pożądanych cech żony należą: ugodowość, troskliwość, wierność i posłuszeństwo. Mąż ceni sobie jej urodę oraz dbałość o tradycję.

W towarzystwie innych nie zachowuje się jak jej partner. Małżonka nie może publicznie mu się sprzeciwić. Dopiero, gdy wokół nich nie ma nikogo kobieta może liczyć na zrozumienie i pomoc ze strony męża. Jest to dowodem na dwoistość w traktowaniu kobiet. To co widzimy na zewnątrz różni się od świata ich kontaktów małżeńskich.

Po ślubie młoda mężatka przenosi się do domu swojej teściowej. Wynika to przede wszystkim z młodego wieku małżonków, którzy nie są w stanie samodzielnie się utrzymać. Decyzja ta związana jest również z przygotowaniem kobiety przez teściową do bycia żoną swego syna. Młode małżeństwo może się usamodzielnić wówczas, gdy pojawi się ich potomstwo.

\footnotetext{
${ }^{6}$ Wyniki Narodowego Spisu Powszechnego Ludności i Mieszkań 2002..., op. cit.

${ }^{7}$ S. Sykuna, Kiedy prawo zderza się z tradycja i obyczajami..., w: Tożsamość kulturowa Romów w procesie globalizacji, pod red. T. Palecznego, J. Palewicz-Kwiatkowskiej, Kraków 2008, s. 87.
} 
W środowisku romskim, przeciwnie do świata gadziów, nie wolno mówić, że kobieta spodziewa się dziecka. Jest to temat tabu, ponieważ wiąże się z seksem, o którym rozmowa jest kalająca. Dopiero, gdy ciąża jest widoczna można przekonać się o brzemienności kobiety. Gdy romni jest w ciąży, to nie może uczestniczyć w pogrzebie lub być jego świadkiem. Poza tym, istnieją inne czynności, których nie może wykonywać kobieta, aby chronić swoje dziec$\mathrm{ko}^{8}$. Podobnie, jak o ciąży nie rozmawia się publicznie o porodzie. Kobietom zakazuje się dokonywania aborcji. Akt ten uchodzi za niemoralny i wymierzony przeciwko życiu innego członka społeczności romskiej.

Wspomniany już wcześniej kodeks postępowań czyli romanipen wprowadził pojęcie czystości rytualnej. Przekroczenie jej może spowodować skalanie i stan nieczystości. Sytuacja ta może być wywołana przez pewne części ciała wraz z ich wydzielinami ${ }^{9}$. Do nieczystych należy ciało kobiety od pasa w dół wraz z bielizną i obuwiem (będącymi w bezpośrednim kontakcie z ciałem). Kobieta ma moc kalającą od pierwszej menstruacji aż do menopauzy. Kontakt mężczyzny z tym częściami wraz z przylegających do nich rzeczami może skończyć się skalaniem. Skutkuje to samotnością i wykluczeniem. Nikt z takim mężczyzną nie będzie rozmawiał, spożywał wspólnie posiłków, siedział przy stole do czasu ściąnnięcia skalania. Skalany Rom nazywa się magerdo. O długości trwania kary i jego przebiegu decyduje Siero Rom czyli głowa lub król romski albo Kris (sąd romski) u Lowarów i Kełderaszy.

Z uwagi na moc kalającą kobiety, pochodzące $\mathrm{z}$ grup przestrzegających surowo wszystkich zasad, muszą dbać również o to by ich bielizna nie była prana z rzeczami męskimi. Ponadto mają zakaz siadania na stole i dotykania krawędzi stołu dolną partią ciała. W dawnych czasach noszenie kilku spódnic przez kobietę miało oddzielać jej nieczystą część ciała od świata czystego. Kalająca jest również sytuacja, gdy kobieta znajduje się nad mężczyzną. Zatem zgodnie z tradycją Rom może zajmować tylko najwyższą kondygnację w budynku, by uniknąć sytuacji przebywania nad nim kobiety. Projekt domu jest również tak przemyślany, aby spiżarnia nie znalazła się pod kuchnią. W niej najczęściej przebywa kobieta, która przemieszcza się nad żywnością przechowywaną w tym pomieszczeniu i tym sposobem czyni ją niejadalną. Dotyczyć to może także sytuacji, w której dochodzi do awarii samochodu. Mężczyzna wejdzie pod samochód tylko wtedy, gdy kobieta z niego wyjdzie.

Kodeks postępowań dzieli skalania na małe (tikne mageripena) i duże (bare mageripena). Dotyczą one między innymi relacji między mężczyzną a kobietą. Wywierają wpływ na niższą pozycję kobiet w środowisku romskim. Zakładają, że kobieta z samej natury jest nieczysta. Powodują, iż przez większość czasu jest ona skalana. Romanipen wymienia cztery rodzaje skalań. Do nich zalicza się ${ }^{10}$ :

— Dźuvlitko Mageripen. Jest to skalanie odnoszące się do intymnej sfery życia. Dotyczy okresu od pierwszej menstruacji aż do menopauzy. Wiąże się ono z seksem i wszelkimi odchyleniami od normy w stosunkach seksualnych (całowanie nieczystych części ciała żony). Prawdopodobieństwo zostania skalanym w tym przypadku nie jest duże. Zachowania te należą bowiem do sfery prywatności i dopiero, gdy ktoś będzie świadkiem takich czynów lub żona fakt taki upubliczni, to jest podstawa do wykluczenia i mężczyzna staje się magerdo;

\footnotetext{
${ }^{8}$ Więcej o tym: A. J. Kiwerska, Polska Roma. Tradycja i nowoczesność, Warszawa 2005, s. 61-63.

${ }^{9}$ Ibidem, s. 178.

${ }^{10}$ Opracowane na podstawie J. Ficowski, Cyganie w Polsce. Dzieje i obyczaje, Warszawa 1989, s. 61-63; A. J. Kiwerska, Polska Roma..., op. cit., s. 37.
} 
- Podźitko Mageripen, czyli spódnicowe skalanie (podźa oznacza spódnicę). Ta część garderoby jest nieczysta. Pełni rolę broni, której może użyć kobieta (w obronie swego dobrego imienia) przeciwko mężczyźnie. Skalanie to polega po prostu na celowym uderzeniu mężczyzny spódnicą. Wykluczeniem może zakończyć się także przypadkowe dotknięcie spódnicy kobiety przez mężczyznę;

- Terachitko Mageripen (od słowa terach, czyli pantofel). Jest to trzewikowe skalanie, które ma miejsce po celowym dotknięciu mężczyzny butem kobiety. Zaliczane jest ono do kolejnych możliwości samoobrony kobiety przed mężczyzną;

- Mamitko lub Mamiakro Mageripen. Skalanie to dotyczy nieczystości kobiety podczas porodu, po porodzie (od 3 tygodni do pół roku ${ }^{11}$ ) i w czasie menstruacji. Sam akt wydawania dziecka na świat jest już nieczysty i powinien odbyć się poza miejscem zamieszkania rodziny (domem, mieszkaniem). Kobietom romskim nie towarzyszą wówczas ich mężowie (gdyby do tego doszło byliby magerdo). Kobieta w wymienionych sytuacjach odsunięta jest od zajęć domowych (nie przygotowuje posiłków, nie sprząta) i korzysta z wydzielonych naczyń. Jest izolowana od reszty domowników. Jej azylem jest pokój, w którym przebywa wraz z dzieckiem (mającym również właściwości kalające. Dlatego też ojciec dziecka nie bierze go publicznie na ręce przez parę tygodni). Kobieta sama lub po zasięgnięciu opinii starszej od siebie podejmuje decyzję o powrocie do społeczności.

Kobiecość w środowisku romskim nie może być eksponowana. Jej atrakcyjność lub seksualność nie jest przedmiotem publicznych rozmów.

Kobiety romskie dopiero w wieku dojrzałym (około 60 roku życia) zasługują na szacunek i równouprawnienie. Phuri daj może zasiadać z mężczyznami przy jednym stole i brać udział w dyskusji. Wysoka pozycja takiej kobiety wiąże się z tym, iż nie jest już przyczyną części skalań. Poza tym Romowie obdarzają ogromnym szacunkiem ludzi starszych niezależnie od stopnia pokrewieństwa ${ }^{12}$. Taką kobietę musi cechować nieskazitelna opinia środowiska romskiego. Musi być zatem patywa (godna szacunku) ${ }^{13}$. Powinna mieć tylko jednego męża, wychować dzieci zgodnie z tradycją i stronić od jakichkolwiek skandali ${ }^{14}$. Poza nią autorytet wśród Romów ma także żona przywódcy (króla).

Współczesne kobiety są częściej dwujezzyczne niż ich matki czy babcie. Częściej wchodzą w kontakt z gadziami, chodzą do szkół i zdobywają wykształcenie. Częściej także zdają sobie sprawę z drugorzędnej roli i dążą do osiągnięcia własnych celów. Efektem zmian w świecie romni z przełomu XX i XXI wieku jest wydłużenie wieku zamążpójścia, większa troska o swój wygląd polegająca na robieniu makijażu, noszeniu modnej odzieży, odsłonięciu ciała (spódnice są krótsze i nie zakrywają już całych nóg). Nowoczesne romni w wielu przypadkach zostają współmałżonkami gadziów. Chcą mieć wpływ na to kto zostanie ich mężem.

Proces emancypacji nie ma jednak charakteru powszechnego. Tradycja zbyt mocno jest zakorzeniona. Kobiety nie dazżą do całkowitego zniesienia zasad i tym samym zrównania praw z mężczyznami. Zmierzają przede wszystkim do uelastycznienia obowiązujących norm, szacunku i większej otwartości na zewnątrz. Nadal pozostają strażniczkami tradycji oraz dużą rolę przywiązują do rodziny.

\footnotetext{
${ }^{11}$ A. J. Kiwerska, Polska Roma ..., op. cit., s. 70-71.

12 Ibidem, s 177.

13 Ibidem, s. 31.

${ }^{14}$ Ibidem, s. 31-32.
} 
Przemiany w świecie kobiet romskich doprowadziły do powołania typowo kobiecych organizacji. Jedną z nich jest Stowarzyszenie Kobiet Romskich w Polsce z siedzibą w Krakowie (założone w 2000 roku). Na jego czele stoi Krystyna Gil. Wśród wielu celów członkinie tej organizacji postawiły przed sobą wskazywanie dróg do samodzielnego myślenia i sterowania swoim własnym życiem ${ }^{15}$. Inną instytucją skupiającą romni jest Stowarzyszenie Kobiet Romskich Kcher, powstałe w 2004 roku w Tarnowie ze Zdzisławą Kudlą, jako przewodnicząca.

Spośród czterdziestu trzech organizacji działających na rzecz społeczności romskiej, kobiety przewodniczą dziesięciu z nich. Można powiedzieć tylko tyle lub aż tyle. Poza wyżej wymienionymi są wśród nich: Izabela Jaśkowiak (przewodnicząca Romskiego Stowarzyszenia Oświaty Harangos), Teresa Skrapska (stoi na czele Stowarzyszenia Romów w Legnicy), Ewa Krzyżanowska (Stowarzyszenie Nowa Roma w Lublinie), Helena Laski (Stowarzyszenie Romów i Innych Narodowości w Nysie), Krystyna Markowska (Centrum Doradztwa i Informacji dla Romów w Polsce z siedzibą w Pabianicach), Anna Markowska (Fundacja Bahtałe Roma - Szczęśliwi Cyganie w Poznaniu), Zofia Czarnecka (Stowarzyszenie Niepełnosprawnych Romów w Świecie), Żaneta Nowicka (Towarzystwo Rodziców Uczniów Romskich Nelo Dom - Nowa Droga we Wrocławiu) ${ }^{16}$. Zmiany w środowisku romskim zaowocowały wejściem kobiet do Zespołu do spraw Romskich wchodzącego w skład Komisji Wspólnej Rządu i Mniejszości Narodowych i Etnicznych ${ }^{17}$. Na dwudziestu ich członków jest sześć kobiet (Stanisława Mirga - kierownik przedszkola romskiego, Inga Mirga, Sylwia Maroń - asystentki edukacji romskiej, Krystyna Markowska - Centrum Doradztwa i Informacji dla Romów w Polsce, Ewa Krzyżanowska - Stowarzyszenie Nowa Roma, Izabela Jaśkowiak - Romskie Stowarzyszenie Oświaty Harangos).

Aktywność romni widoczna jest także w dziedzinie oświaty. Zostają one asystentkami romskimi w szkołach. Wspomagają edukację dzieci opóźnionych w nauce, służą pomocą przy odrabianiu lekcji i rozwiązywaniu sytuacji konfliktowych w palcówkach oświaty. Towarzyszą im przy wycieczkach, zabawach. Społeczność romska obdarza je zaufaniem i szacunkiem, na czym korzystają przede wszystkim dzieci (których średnia ocen podnosi się i zmniejsza się absencja). Kobiety romskie wchodzą ponadto do świata mass mediów. Są dziennikarkami, jak Agnieszka Gabor - współpracowniczka programu Etniczne klimaty i redaktorami naczelnymi czasopism - Karolina Stankiewicz miesięcznika Rrom po Drom. Piastują również urzędy państwowe, czego przykładem może być Elżbieta Mirga-Wójtowicz (pełnomocnik wojewody małopolskiego ds. mniejszości narodowych i etnicznych).

Poza wyżej wymienionymi kobietami wiele innych romni chciałyby zdobyć zawód i pracować. Na przeszkodzie nadal stoi nieufność wobec Romów, niedostateczne ich wykształcenie oraz nieznajomość reguł obowiązujących przy zakładaniu własnej działalności. Problemem jest także podtrzymywanie tradycji wędrowania. Zmiany miejsca pobytu nie sprzyjają wypełnianiu obowiązków w pracy zawodowej. Ponadto kłopotliwe może być także oddanie się pracy kosztem dbałości o dzieci i męża, które jest nakazem żony.

Na pomoc kobietom (i mężczyznom) wychodzi obecnie wiele organizacji romskich oraz instytucji non-profit. Korzystając ze środków unijnych, na przykład w ramach Programu Operacyjnego Kapitał Ludzki, przygotowują różnego rodzaju kursy. Często jednak nie przy-

\footnotetext{
${ }^{15} \mathrm{http}: / /$ kobietyromskie.free.ngo.pl/x/index.html (2.05.2011).

${ }^{16}$ Opracowanie na podstawie http://harangos.pl/organizacje-romskie (2.05.2011).

${ }^{17}$ Została ona utworzona na podstawie art. 23 ust. 1 ustawy z dnia 6 stycznia 2005 roku o mniejszościach narodowych i etnicznych oraz o języku regionalnym (Dz. U. 2005, Nr 17, poz. 141). Komisja uznana została za organ opiniodawczo-doradczy Prezesa Rady Ministrów. Romów reprezentują Roman Chojnacki i Robert Bladycz.
} 
stają one do rzeczywistych potrzeb. Przykładem mogą być szkolenia komputerowe czy menadżerskie. Umiejętności zdobyte podczas tygodniowego lub trzygodniowego takiego kursu nie pomogą im w znalezieniu pracy. Przy braku elementarnej wiedzy (nie ukończona szkoła podstawowa, analfabetyzm), zawodu i utrzymujących się negatywnych stereotypów ich szanse są niewielkie.

Kobiety romskie są ofiarami przemocy domowej i seksualnej. Rzadko jednak informacje te wychodzą poza ich świat. Sytuacja ta ma związek z tym, iż seksualność jest uznawana za temat tabu. Decydujące znaczenie ma również inna z zasad romskich, która nie pozwala donosić na innego Roma Policji czy wytoczyć mu postępowania przed sądem. Podejmując decyzję o zgłoszeniu przestępstwa narusza kodeks postępowania i naraża się na wewnętrzne odrzucenie (gdy sprawcą jest osoba pochodzenia romskiego).

Romni doświadczają również prześladowań i dyskryminacji ze strony gadziów. O wielu przypadkach niewłaściwego zachowania wobec nich donoszą raporty przygotowywane przez polskie, jak i międzynarodowe instytucje. Najobszerniejszy z nich opracowany został przez Europejskie Centrum Praw Romów. W nim odnotowano na przykład: incydenty pobić kobiet romskich na ulicach polskich miast i niszczenia ich mienia (mieszkań), bezczynność Policji w sytuacjach zastraszania romni, odrzucania ich podań w sprawie przyznania mieszkania komunalnego, odmówienia udzielenia pomocy lekarskiej, niechęć do zatrudniania kobiet romskich, dyskryminowanie ich w dostępie do pomocy społecznej ${ }^{18}$.

Położenie romni na terenie Polski i innych państw europejskich nie jest zadawalające. Przykłady licznych form ich dyskryminacji oraz chęć poprawy życia legły u podstaw wydania przez Parlament Europejski rezolucji w sprawie sytuacji kobiet romskich w Unii Europejskiej $^{19}$. W dokumencie tym wezwano między innymi do: poprawy warunków mieszkaniowych, większej dostępności kobiet do służby zdrowia, podniesienia współczynnika scholaryzacji wśród romni, wspierania samozatrudnienia kobiet romskich i rozwoju ich przedsiębiorczości. Uzupełnieniem tego aktu jest rezolucja Parlamentu Europejskiego w sprawie europejskiej strategii dotyczącej Romów z 2008 roku.

Bycie romni w XXI wieku jest bez wątpienia trudne. Wiąże się to z życiem na pograniczu dwóch światów i kultur, co może rodzić dyskomfort i problemy tożsamościowe. Nie jest to z pewnością dla nich nowa sytuacja. Jednak współcześnie w dobie globalizacji, postępującej technologii i zmieniającym się otoczeniu trwanie przy tradycji wymaga większego wysiłku.

Poza tym obserwuje się powoli rosnącą otwartość obu stron (Romów i gadźiów), a to również może zwiastować pewne zmiany. Kobiety romskie częściej niż kiedykolwiek przejmują inicjatywę i są aktywne zawodowo. Tworzą organizacje i reprezentują je na zewnątrz. Ich obraz i pozycja ulega przekształceniu. W związku z tym nasuwa się kilka pytań. Interesujące jest na przykład z jakich grup i rodzin owe kobiety pochodzą? Czy na ich postawę wpływ wywarła rodzina czy otoczenie? Jaka jest reakcja męskiej części ich środowiska? Jak będą wychowywać swoje córki?

W globalizującym się świecie jedynie analfabetyzm, słabe wykształcenie, brak znajomości języka polskiego, odcięcie od nowoczesnych mediów oraz trwanie w tradycji i przestrzeganie romanipen nie zmieni szybko romskich kobiet. Nadal będą skromne i uległe, a ich decyzje będą miały drugorzędną rolę. Być może takie życie, jakie toczyły ich matki i babcie

${ }^{18}$ Granice solidarności. Romowie w Polsce po roku 1989, Warszawa 2003 oraz A. Adamczyk, Romowie problem krajowy czy europejski? Sytuacja Romów w świetle wybranych raportów, w: Unia na rozdrożu. Wybrane problemy, pod red. A. Adamczyk, Poznań 2008.

${ }^{19}$ www.rownetraktowanie.gov.pl/files/dokumenty/Rezolucje PE/REZ_P6_TA(2006)0244.pdf (2.05.2011). 
im odpowiada. Lokalne wspólnoty zabiegają o to, aby jak najmniej członków ich zbiorowości wyszło poza granice tego co romskie i czyste. Dotyczy to szczególnie kobiet, które są nośnikami tradycji.

\section{Summary}

\section{Romni among the Romani. Women in Romani Culture}

The paper discusses the position of women in Romani society. The author presents the various roles a romni (Romani for woman) plays. She refers to the rules of the moral and ethical code (romanipen) that significantly affects female behavior, determines the relationship between females and males, and assigns women a lower position in society than men. The paper also discusses the 'impurities' that constitute a specific weapon Romani women can wield against men.

The author observes the changes that are taking place in the world of modern romnis. They are increasingly more educated, professionally active and make independent decisions concerning their own future. It should be borne in mind, however, that they continue to live in a closed community that guards its traditions, language and privacy. To change the life of Romani women would mean their leaving this community and abandoning the fundamental principles of Romani life, which is difficult. Romani women do not struggle for these principles to be abandoned completely, thus giving them equal rights. They continue to guard their traditions and hearth and home. 